\section{Jurnal Kimia Sains dan Aplikasi Journal of Scientific and Applied Chemistry}

Journal homepage: http://ejournal.undip.ac.id/index.php/ksa

\title{
Effect of Sulfur Addition to Nickel Recovery of Laterite Ore
}

\author{
Eni Febriana ${ }^{a,{ }^{*}}$, Agus Budi Prasetyo a , Wahyu Mayangsari ${ }^{a}$, Januar Irawan a , \\ Muhammad Ikhwanul Hakim $^{\mathrm{b}}$, Tiffany Ary Prakasab ${ }^{\mathrm{b}}$, Andinnie Juniarsih ${ }^{\mathrm{b}}$, Ariyo Suharyanto ${ }^{\mathrm{a}}$, \\ Iwan Setiawan ${ }^{a}$, Rudi Subagja ${ }^{a}$ \\ ${ }^{a}$ Pusat Penelitian Metalurgi dan Material, Lembaga Ilmu Pengetahuan Indonesia (LIPI), Puspiptek Setu, Tangerang Selatan, Indonesia \\ ${ }^{\mathrm{b}}$ Teknik Metalurgi Universitas Sultan Ageng Tirtayasa, Cilegon, Banten, Indonesia \\ * Corresponding author: enifo01@lipi.go.id \\ https://doi.org/10.14710/jksa.23.1.14-20
}

\section{Article Info}

Article history:

Received: $20^{\text {th }}$ August 2019

Revised: $11^{\text {th }}$ November 2019

Accepted: $17^{\text {th }}$ December 2019

Online: $31^{\text {st }}$ January 2020

Keywords:

nickel ore; limonite;

reduction; additives; sulfur

\section{Abstract}

This research studied the effect of the addition of sulfur on the reduction process of limonite nickel laterite ore with Ni content of $1.11 \mathrm{wt} \%$ and Fe $48.7 \mathrm{wt} \%$. The stages of the research included the characterization of ore materials, preparation, mixing, pelleting, reduction, and magnetic separation. The reduction stage was carried out with several experimental variables, which were the time and temperature of the reduction, as well as the addition of reducing agents and sulfur additives. Products from the reduction process were separated magnetically, and the concentrate was then analyzed using XRD and AAS. The results showed that the addition of sulfur additives to a certain amount could cause the formation of FeS and Fe-silicate, which could increase the content and percentage of nickel recovery by suppressing the metallization of iron. The optimum conditions were obtained in the reduction process with a temperature of $1100^{\circ} \mathrm{C}$ for 60 minutes, with the addition of graphite reductant and sulfur additives each of $7 \%$ of the sample weight. Ni contents in the reduction product concentrate obtained were $1.98 \%$ with $96 \%$ gain, while Fe could be reduced to $29.2 \%$ with an extraction percentage of $76.1 \%$.

\section{Introduction}

Laterite ore is the primary source of nickel, which covers almost $60 \%$ of the total nickel reserves in the world [1]. Laterite ore is widely distributed, especially in the tropics. Based on data from the ESDM Data Review Center in 2012, in Indonesia alone, the potential for laterite nickel was estimated at 1,878 million tons with an average nickel content of $1.45 \%$ spread across Sulawesi, Kalimantan, Maluku, and the Papua regions [2]. The amount of reserves is ranked fourth in the world, with a percentage of $12 \%$ [3]. This potential certainly provides an excellent opportunity for Indonesia because of the increased projected demand for nickel until 2025, while world nickel production tends to decrease due to the depletion of nickel sulfide reserves $[4,5]$.
Laterite nickel is usually formed as a residual product of chemical weathering in ultramafic rocks that contain ferromagnetic materials such as olivine, pyroxene, and amphibole. Laterite ores have an average of $<2 \%$ nickel content, which is generally in the goethite $(\mathrm{FeOOH})$ crystal lattice [6]. Nickel is spread out throughout the ore, and it is difficult to increase its content using the usual physical beneficiation method [3]. This condition prompted the researchers to develop new methods, one of which is through the reduction roasting pathway, which reduces $\mathrm{NiO}$ to metallic nickel and separates it from iron impurities [7]. This process is possible to be carried out thermodynamically, but in practice, there are problems in determining the reduction temperature. At $600^{\circ} \mathrm{C}, \mathrm{NiO}$ has been reduced to metallic nickel, but the particle size is still too small to be separated by magnetic separation [8]. Conversely, if the reduction process is carried out at a 
temperature of $1000^{\circ} \mathrm{C}$ will produce large metallic particles, but the reduction rate of $\mathrm{Fe}$ oxides also increases, which causes a decrease in nickel content [9].

Several previous studies have shown that the reduction of metallic particles can be enlarged by adding additives containing sulfur. Some additional elements, such as adding iron content to the ore, can also increase nickel yield [10]. But at this time, the addition of sulfur is widely studied because sulfur is known to reduce the surface tension of metal particles so that the particle size can grow larger [11]. Zhu et al. [12] roasted laterite nickel reduction at $1100^{\circ} \mathrm{C}$ for 60 minutes with a $6 \% \mathrm{CaSO}_{4}$ additive. From his research, the ferronickel concentrate was obtained with $6 \% \mathrm{Ni}$ content and $92.1 \%$ recovery. Setiawan et al. [13] conducted a study of carbothermic reduction using sub-bituminous coal containing sulfur, which was followed by magnetic separation, and the result obtained was an increase in nickel content up to $5 \%$ (weight). Li et al. [14] conducted a study of nickel laterite reduction at $1100^{\circ} \mathrm{C}$ for 60 minutes with the addition of $20 \% \mathrm{Na}_{2} \mathrm{SO}_{4}$ additive. The result is a ferronickel concentrate with $\mathrm{Ni}$ content reaching $9.48 \%$, but the recovery is only $83.01 \%$.

This research was conducted to determine the right combination between the amount of reducing agent and sulfur to be added in the process of selective reduction of laterite nickel reduction with graphite reducing agent and the addition of sulfur additives. The effect of process variables such as reduction time, reductant addition, temperature, and sulfur addition was determined quantitatively.

\section{Methodology}

\subsection{Material and Tools}

The raw material used in this study was laterite ore from Sangaji Halmahera. The chemical composition of laterite ore samples was analyzed using XRF (X-Ray Fluorescence) Panalytical Epsilon 1. The results showed that the iron and silica content in laterite ore was quite high, $69.6 \%$, and $14.8 \%$, respectively, as $\mathrm{Fe}_{2} \mathrm{O}_{3}$ and $\mathrm{SiO}_{2}$. The total Ni contained in the ore was quite low, only around $1.11 \%$. XRD analysis (X-Ray Diffraction), which is a qualitative analysis of minerals, was then determined using PANalytical X'Pert Pro MPD XRD with $\mathrm{Cu}$ Ka radiation $(\lambda=1.5406 \AA)$. The generator was operated at a voltage of $40 \mathrm{kV}$, an electric current of $30 \mathrm{~mA}$, a measurement speed of $2 \% \mathrm{~min}$, and a sampling pitch of $0.020^{\circ}$. Following the results of previous studies, it was known that the laterite ore used was a type of limonite which was dominated by the structure of the mineral goethite and had low Ni contents [15]. The compounds contained in the ore consist of quartz minerals $\left(\mathrm{SiO}_{2}\right)$, goethite $(\mathrm{FeO}(\mathrm{OH}))$, hematite $\left(\mathrm{Fe}_{2} \mathrm{O}_{3}\right)$, and lizardite $\left(\mathrm{Mg}_{3}\left(\mathrm{Si}_{2} \mathrm{O}_{5}\right)(\mathrm{OH})_{4}\right)$ [16]. Limonite ore was first dried in an oven for 12 hours at a temperature of $110^{\circ} \mathrm{C}$, crushed with a jaw crusher, crushed with a disk mill, then sieved to obtain granules with a size of 74 microns.
In the reduction process, graphite reductant was used as carbon sources, with a fixed carbon value of $96.8 \%$ to minimize the effects of impurities such as volatile matter and water content on the reduction process. Additives added in the form of sulfur from nature. The graphite and sulfur that was used go through the process of crushing, grinding, smoothing and sieving like the limonite ore to pass a 44-micron sieve to ensure that the material was entirely distributed in the mixture of material to be reduced. Laterite ore was then mixed with graphite and sulfur in a specific ratio then formed into pellets to obtain an even heat distribution during the reduction process.

\subsection{Experiment}

Selective reduction experiments were carried out in a Carbolite CWF 1300 type muffle furnace. A certain amount of pellet was inserted into a graphite crucible and covered with a layer of glass wool and charcoal to ensure the conditions inside the crucible remained reductive. The crucible containing the sample was put into a muffle furnace at room temperature. The furnace was heated to a certain temperature then held with a variation of the reduction time of $30-180$ minutes. The reduction temperature was $800-1100^{\circ} \mathrm{C}$, as well as the addition of reductant agents and additives, each of which was $0-21 \%$. The reduced sample was cooled slowly in the furnace until it reached room temperature, then permanently separated (permanent hand magnetic) therefore, there was a separation between the concentrate containing a lot of ferronickel metal and tailings. The concentrate was weighed and analyzed using XRD (X-Ray Diffraction) and AAS (Atomic Absorption Spectrophotometer).

The addition of reductants and additives was based on the stoichiometry calculation of the reactions that occurred, then the amount was varied with less amount than stoichiometry and exceeded stoichiometry.

Analysis of Ni and Fe content was calculated based on measurement results using AAS (Atomic Absorption Spectrophotometer), while the recovery was calculated using equation (1):

$\%$ Recovery $=\frac{(\text { metal content in concentrate } \mathrm{x} \text { mass of concentrate })}{(\text { metal ore content } \mathrm{x} \text { ore mass })} \times 100 \%$

\section{Result and Discussion}

The effect of various parameters of the reduction process was carried out by determining changes in the contents of $\mathrm{Ni}$ and $\mathrm{Fe}$ in the reduction process product concentrate, as well as the percentage of its recovery.

\subsection{Effect of Reduction Time}

One of the variables that significantly influence the results of the selective reduction process was the length of the reduction process. Theoretically, the longer the reduction process, the more metal phase formed [17]. The reduction time was varied for $30,60,120$, and 180 minutes with a temperature of $1100^{\circ} \mathrm{C}$, the reducing agent and sulfur were $7 \%$ by weight of the limonite ore sample, 
respectively. The results of the AAS analysis of the reduced $\mathrm{Ni}$ and Fe contents at various time variations are shown in Figure 1.
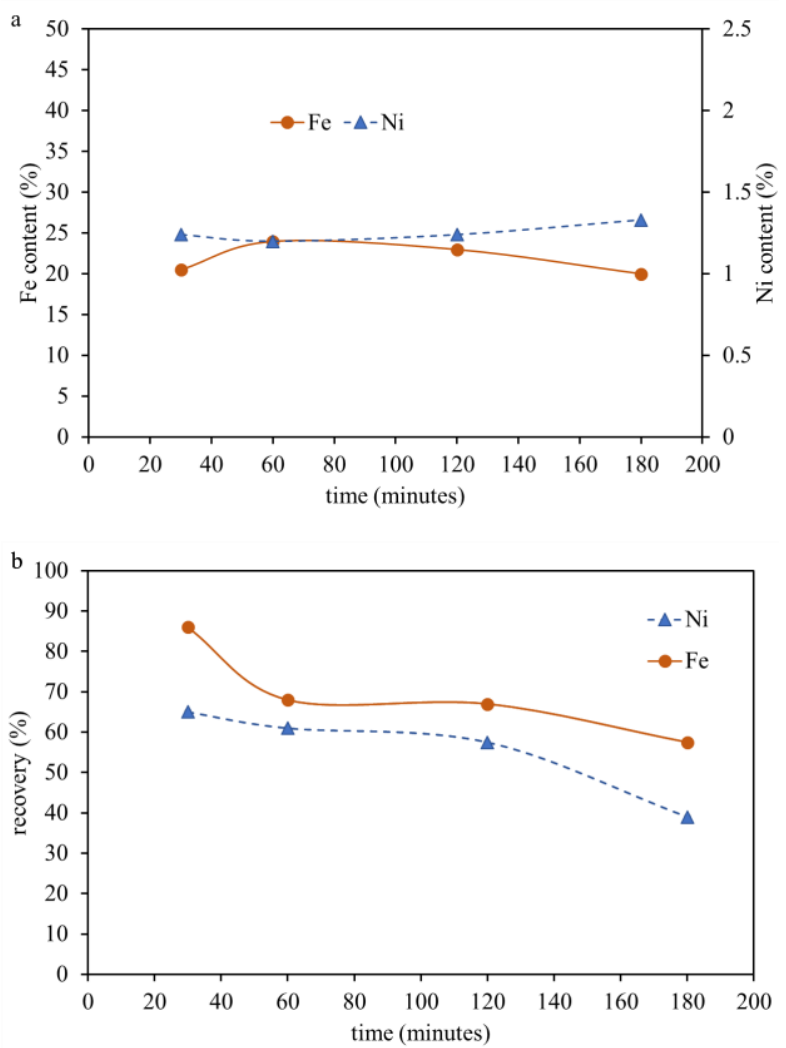

Figure 1. The effect of reduction time to the concentrate of reduction product (a) the content of $\mathrm{Ni}$ and $\mathrm{Fe}$ (b) the recovery of $\mathrm{Ni}$ and $\mathrm{Fe}$

Figure 1 shows that in the first 30 minutes of reduction, Ni contents increased from $1.11 \%$ in the initial sample to $1.24 \%$. The maximum increase in Ni contents reached $1.34 \%$ after a reduction of 180 minutes. Increasing Ni contents caused a decrease in Fe contents so that the tendency of the curve is vice versa. Overall, the Fe content decreased significantly from the initial sample that had a total Fe content of $48.72 \%$ to $24.2 \%$ with a reduction time of 60 minutes. The decrease in Fe contents was also accompanied by a significant decrease in Fe recovery from a reduction time of 30 minutes to 60 minutes. The addition of a reduction time of 180 minutes increases the reduction in Ni recovery by $25 \%$ with a less significant decrease in Fe recovery. Therefore, 60 minutes is the optimum reduction time because there is an increase in $\mathrm{Ni}$ contents that were obtained with a substantial reduction in Fe recovery. That is possible due to the influence and the presence of sulfur, which were added as an additive in the reduction process. Sulfur can bind iron to become FeS and increase the nickel content of the reduced product concentrate [18]. A description of the reactions that occur between $\mathrm{Fe}$ and $\mathrm{S}$ is presented in more detail in section 3.4. The longer the reduction time, the higher the Fe metallization, hence the higher the FeS formed and separated in the tailings. This causes the number of residues to increase, and the recovery of concentrates gets smaller, so, despite an increase in $\mathrm{Ni}$ contents, the percentage of recovery is small.

\subsection{Effect of Reduction Temperature}

The effect of the reduction temperature on the reduction process was observed at temperatures of 800 , 900,1000 , and $1100^{\circ} \mathrm{C}$. The selection of the reduction temperature variable was based on the Gibbs energy of metal oxides $\mathrm{NiO}, \mathrm{Fe}_{2} \mathrm{O}_{3}$ and $\mathrm{Fe}_{3} \mathrm{O}_{4}$ and data on the decomposition process of TG-DTA testing on a mixture of limonite and graphite ores that have been performed in previous studies $[16,19]$. $\mathrm{NiO}, \mathrm{Fe}_{2} \mathrm{O}_{3}$, and $\mathrm{Fe}_{3} \mathrm{O}_{4}$ metal oxides can be reduced using carbon to $\mathrm{Ni}, \mathrm{Fe}_{3} \mathrm{O}_{4}$, and $\mathrm{FeO}$ at the lowest temperatures of 435,798 , and $1187^{\circ} \mathrm{C}$, respectively [20].

The reduction experiment for each temperature was carried out for 60 minutes with the addition of graphite reductant and sulfur additives, each of $7 \%$ of the sample weight. Then the reduction of product concentrate was analyzed using AAS to determine the contents of $\mathrm{Ni}$ and Fe metals. Changes in Ni and Fe metals are shown in Figure 2.
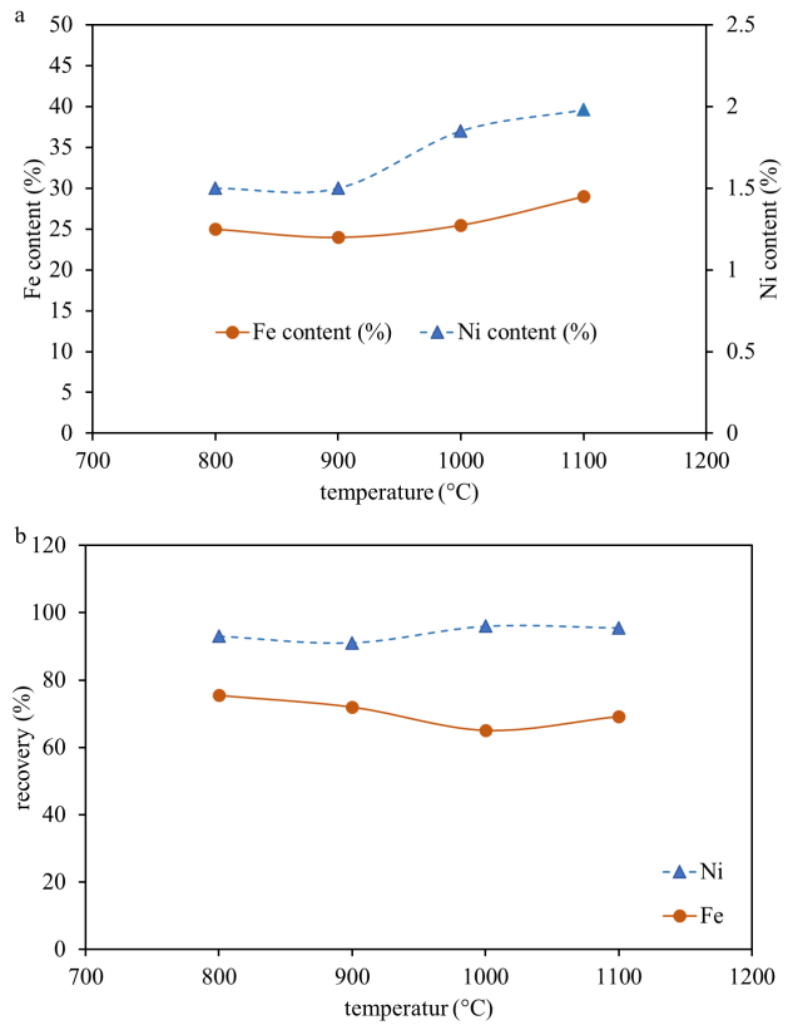

Figure 2. The effect of reduction temperature to the concentrate of reduction product (a) the content of $\mathrm{Ni}$ and $\mathrm{Fe}(\mathrm{b})$ the recovery of $\mathrm{Ni}$ and $\mathrm{Fe}$

After the reduction process, there was an increase in Ni metal content and recovery percentage. Meanwhile, for Fe metals, the content continues to increase as the temperature of the reduction increases, while the percentage of recovery decreases. In $\mathrm{Ni}$ metal, the $\mathrm{Ni}$ content in the reduction product concentration increased from $1.49 \%$ to $1.98 \%$ with a maximum gain of up to $96 \%$ 
at an increase in temperature from 800 to $1100^{\circ} \mathrm{C}$. The Fe metal content increased from $24.7 \%$ to $29.2 \%$, with the recovery percentage decreased from $76.1 \%$ to $70 \%$ due to the same temperature rise. This decrease in the recovery is due to the reduction of oxides that react with carbon so that the mass of the initial sample decrease with increasing temperature. The maximum value is reached at $1100^{\circ} \mathrm{C}$ due to the formation of the kamacite phase. This phase initiates the formation of FeS, which can be separated in the tailings; therefore, $\mathrm{Ni}$ contents and recovery increase.

Temperature is a factor that significantly influences the reduction process [21]. The increasing temperature is causing reduction to take place more correctly, as evidenced by increasing metal content [11]. From the kinetics point of view, an increase in temperature should result in metallic iron and nickel becoming agglomerated and growing into larger particles [12], as well as increasing the liberation of $\mathrm{Ni}$ and Fe-silicates [9]. However, a decrease in the percentage of Fe recovery shows that in the temperature range, the reaction to the formation of Pyrhotit (FeS) is easier than the reduction of iron and nickel. This is in accordance with the study of Zhu et al. [12] that the reduction process with the addition of $\mathrm{CaSO}_{4}$ increased the formation of fayalite (Fe-silicate), which inhibited wustite reduction. More about the effect of adding sulfur to the reduction process is explained in the next sub discussion.

To illustrate the effect of temperature on the reduction of limonite nickel ore, the concentrate of reduction product sample was analyzed using XRD to see the mineral structure formed after the reduction process. The results are shown in Figure 3.

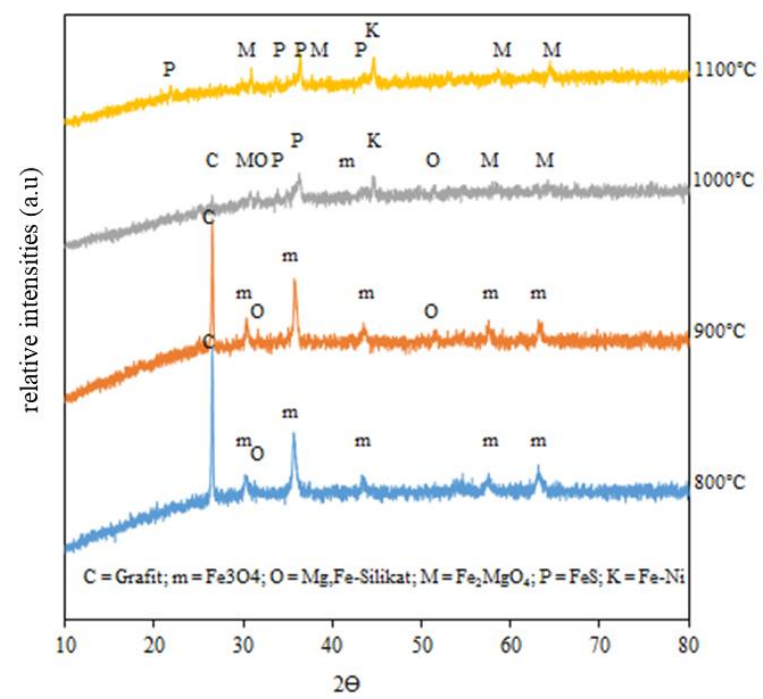

Figure 3. XRD diffractogram of concentrate product reduction at various temperatures.

Based on Gibbs free energy data $\left(\Delta G^{\circ}\right)$ for metal oxides, $\mathrm{NiO}$ has been reduced starting at temperatures of $\sim 430-440^{\circ} \mathrm{C}$ while $\mathrm{Fe}_{2} \mathrm{O}_{3}$ and $\mathrm{Fe}_{3} \mathrm{O}_{4}$ can be reduced using carbon to $\mathrm{Fe}_{3} \mathrm{O}_{4}$ and $\mathrm{FeO}$ at temperatures of 798 and $1187^{\circ} \mathrm{C}$, respectively [20]. At a reduction temperature of 800 and $900^{\circ} \mathrm{C}$, magnetite $\mathrm{Fe}_{3} \mathrm{O}_{4}$ was formed as a result of the reduction of hematite $\left(\mathrm{Fe}_{2} \mathrm{O}_{3}\right)$. Starting at a temperature of $1000-1100^{\circ} \mathrm{C}$, the phases of Kamasite $(\mathrm{Fe}-$ $\mathrm{Ni}$ ), Pyrhotit (FeS), Olivine (Mg-Fe-Silicate), and Magnesiopherite $\left(\mathrm{Fe}_{2} \mathrm{MgO}_{4}\right)$ were presented. Temperature reduction at $800^{\circ}-900^{\circ} \mathrm{C}$ has not given good results for increasing contents and recovery of Ni because the decomposition of graphite as a reducing agent is low. Figure 3 shows that at a temperature of $1000^{\circ} \mathrm{C}$, the carbon intensity decreases significantly, accompanied by the presence of the kamacite and $\mathrm{FeS}$ phases, thereby increasing the reduction temperature to $1100^{\circ} \mathrm{C}$. Carbon can be decomposed as a whole, and the intensity of kamacite increases, so the higher the rate of formation FeS phase can be seen from the higher intensity of the FeS phase peak.

\subsection{Effect of Addition of Reducing Agent}

The more amount of reducing agent added, the higher the content of the metal element in the reduction product concentrate. In this study, the amount of graphite added to the limonite ore sample was $0,7,14$, and $21 \%$ by weight of the sample. The reduction took place at a temperature of $1100^{\circ} \mathrm{C}$ for 180 minutes, with the addition of an additive of $7 \%$ by weight followed by magnetic separation. The results of the analysis of changes in the contents of $\mathrm{Ni}$ and $\mathrm{Fe}$ in the reduction product concentrate and the percentage of recovery of $\mathrm{Ni}$ and $\mathrm{Fe}$ can be seen in Figure 4 .
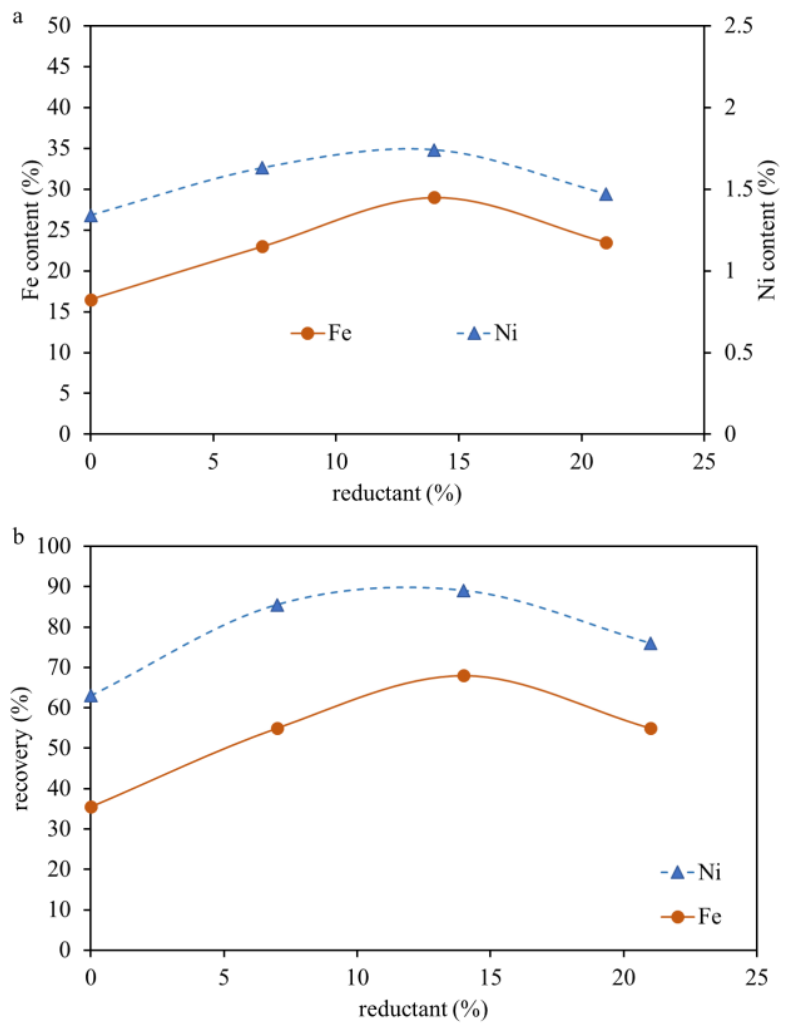

Figure 4. The effect of the amount of reducing agent to the concentrate of reduction product (a) the content of $\mathrm{Ni}$ and $\mathrm{Fe}(\mathrm{b})$ the recovery of $\mathrm{Ni}$ and Fe 
Both iron and nickel have the same tendency towards the effect of reducing agent addition. The addition of $14 \%$ reductant led to an increase in contents and recovery, which respectively reached $29.1 \%$ and $68.2 \%$ for iron, and $1.74 \%$ and $89.4 \%$ for nickel. Furthermore, the value decreases due to the addition of reducing agents by $21 \%$.

The addition of the number of reducing agents allowed the formation of increasingly reductive conditions for the reduction reaction to take place because the CO gas formed upsurged, so it pushed the reaction towards the formation of nickel and iron metals. This was indicated by the increasing contents of $\mathrm{Ni}$ and Fe metals in the concentrate of reduction product along with the rise in the amount of graphite added. However, if the reductant was added excessively the process of agglomeration of small metal particles into larger metal particles was more difficult because besides being hindered by the presence of carbon atoms, the condition of the ore will be less "viscous" so that the movement of metal particles during the reduction process will be hampered [22]. Li et al. [14] stated that when the carbon content has reached an optimal value, the subsequent addition of carbon cause the formation of large amounts of carbon residues, which hinder the process of reduction.

\subsection{Effect of the Addition of Sulfur}

The reduction experiment was carried out by adding a $14 \%$ reductant amount and varying the amount of sulfur added by $0,7,14$, and $21 \%$ by weight of the limonite sample. The reduction reaction was carried out at $1100^{\circ} \mathrm{C}$ for 60 minutes. After the reduction is carried out, continued with magnetic separation to produce a concentrate. Changes in the contents of $\mathrm{Ni}$ and $\mathrm{Fe}$ in the reduction product concentrate, as well as the percentage of recovery of iron and nickel obtained can be seen in Figure 5.

Until the addition of sulfur of $7 \%, \mathrm{Ni}$ contents increased and reached $1.61 \%$ and then decreased with the next addition of sulfur. The maximum percentage of recovery for Ni was $79.2 \%$. With respect to Fe content and percent recovery, the addition of sulfur to the reduced ore tends to cause a decrease of the maximum value of $34.5 \%$ and $87.7 \%$, respectively. This decrease in iron recovery indicates that sulfur influences the selective reduction of laterite nickel ore by the formation of FeS compounds [18]. However, the increase in the percentage content and recovery of Fe occurs with the addition of $14 \%$ sulfur, and this can be due to the presence of $\mathrm{Mg}, \mathrm{Fe}-\mathrm{SiO}_{4}$ phase as shown in Figure 6, where the phase is paramagnetic so that it is possible to increase the amount of magnetic separation increasing the percentage of Fe content and recovery [23].
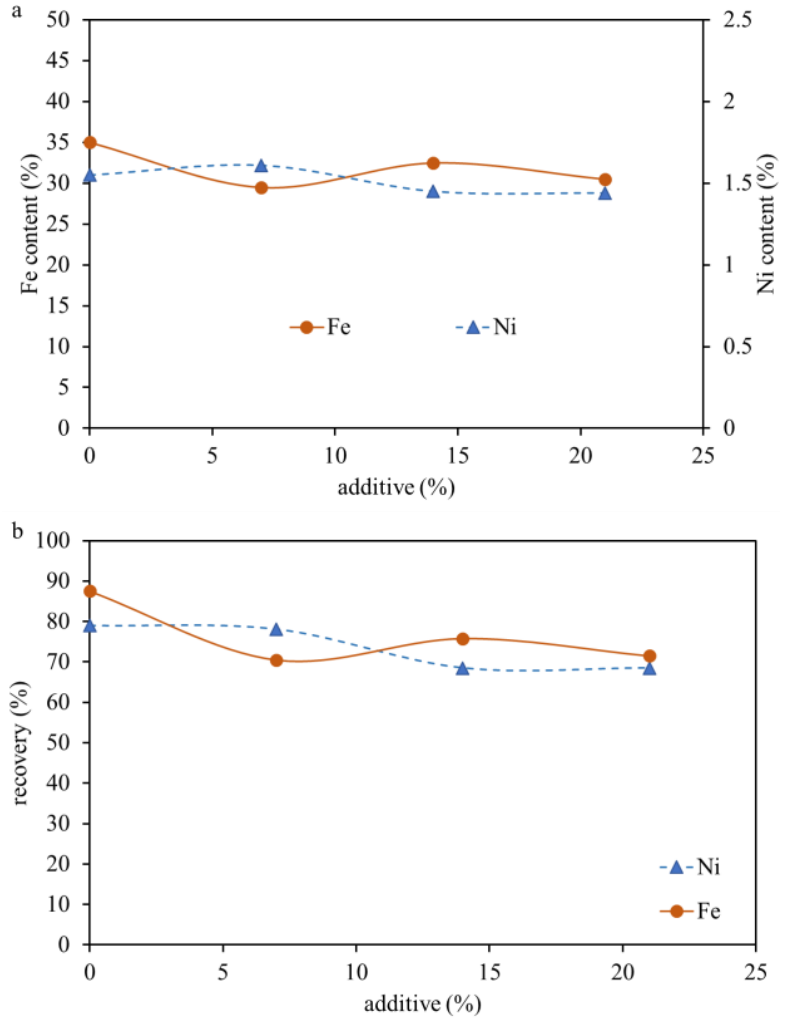

Figure 5. The effect of the amount of sulfur on the concentrate of reduction product (a) the content of $\mathrm{Ni}$ and $\mathrm{Fe}(\mathrm{b})$ the recovery of $\mathrm{Ni}$ and $\mathrm{Fe}$

The combination of controlling the reducing agent contents with the addition of appropriate sulfur compounds makes metallic nickel growth increase [5]. In general, ore, which is roasted with the addition of sulfur, has a loose structure, and FeS cover the metal particles. Sulfur will cover the surface of metallic iron particles and react to form FeS by reaction (1) [18].

$$
\mathrm{Fe}+\mathrm{S} \rightarrow \mathrm{FeS}
$$

The formation of FeS in the reduction process by the addition of sulfur can be explained through the XRD graph, as shown in Figure 6. It can be seen that the reduction process without the addition of sulfur causes the formation of the Kamasite (FeNi) phase with a high enough intensity and the Magnesiopherite $\left(\mathrm{Fe}_{2} \mathrm{MgO}_{4}\right)$ phase is also detected. As the amount of sulfur added to the ore decreases, it increases. The kamacite phase decreases in intensity, followed by the formation of the pyrrhotite (FeS) phase, whose intensity is increasing. As the pyrrhotite $(\mathrm{FeS})$ phase increases, the relative content of nickel to iron in the concentrate will increase. 


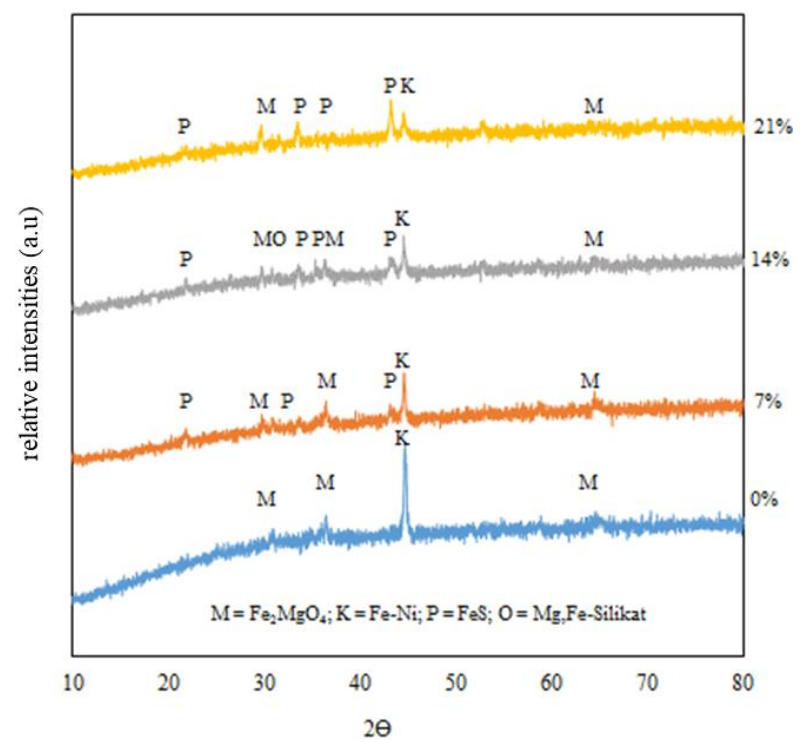

Figure 6. Graph of XRD concentrate product reduction on the various varieties of sulfur addition

\section{Conclusion}

The limonite type of nickel laterite ore reduction process is influenced by the reduction time and temperature, as well as the number of reducing agents and additives. The reduction temperature at $1100^{\circ} \mathrm{C}$ can cause the reducing agent to decompose as a whole so that the intensity of kamacite increases. The addition of sulfur additives to a certain amount can increase the content and percentage of nickel recovery from limonite type nickel laterite ore by suppressing the metallization of iron due to FeS formation. The formation of Fe-silicate, which is paramagnetic and has the potential to increase contents and the recovery of Fe can be overcome by adding sulfur additives of $7 \%$ and a reduction temperature at $1100^{\circ} \mathrm{C}$. The reduction process can be carried out for 60 minutes because although Fe recovery can be reduced by increasing the reduction time, nickel recovery will also decrease significantly if the reduction time is increased.

\section{References}

[1] Baozhong Ma, Chengyan Wang, Weijiao Yang, Fei Yin and Yongqiang Chen, Screening and reduction roasting of limonitic laterite and ammoniacarbonate leaching of nickel-cobalt to produce a high-grade iron concentrate, Minerals Engineering, 50-51, (2013), 106-113

https://doi.org/10.1016/j.mineng.2013.06.014

[2] Pusat Data dan Teknologi Informasi Energi dan Sumber Daya Mineral, Kajian Supply Demand Mineral, in, Kementerian Energi Dan Sumber Daya Mineral, Jakarta, 2013,

[3] Ashok D. Dalvi, W. Gordon Bacon and Robert C. Osborne, The Past and the Future of Nickel Laterites, PDAC 2004 International Convention, Trade Show \& Investors Exchange, (2004)

[4] Peter H. Kuck, U.S. Geological Survey Minerals Yearbook-2012 -Nickel, in, U.S. Geological Survey, 2012,
[5] International Nickel Study Group, Metals Despatch, Newsletter of the International Metals Study Groups, in, International Nickel Study Group, 2016,

[6] Jungah Kim, Gjergj Dodbiba, Hideaki Tanno, Katsunori Okaya, Seiji Matsuo and Toyohisa Fujita, Calcination of low-grade laterite for concentration of Ni by magnetic separation, Minerals Engineering, 23, 4, (2010), 282-288 https://doi.org/10.1016/j.mineng.2010.01.005

[7] C. T. Harris, J. G. Peacey and C. A. Pickles, Selective sulphidation and flotation of nickel from a nickeliferous laterite ore, Minerals Engineering, 54, (2013), 21-31 https://doi.org/10.1016/j.mineng.2013.02.016

[8] Hadi Purwanto, Taihei Shimada, Reijiro Takahashi and Jun-ichiro Yagi, Recovery of Nickel from Selectively Reduced Laterite Ore by Sulphuric Acid Leaching, ISIJ International, 43, 2, (2003), 181-186 https://doi.org/10.2355/isijinternational.43.181

[9] M. Valix and W. H. Cheung, Study of phase transformation of laterite ores at high temperature, Minerals Engineering, 15, 8, (2002), 607-612 https://doi.org/10.1016/S0892-6875(02)00068-7

[10] I. Setiawan, E. Febrina, A. B. Prasetyo, R. Subagja and F. Firdiyono, The effect of iron content on the reduction of nickel laterite by direct reduction method, IOP Conference Series: Materials Science and Engineering, 541, (2019), 012039 https://doi.org/10.1088/1757-899x/541/1/012039

[11] M. Valix and W. H. Cheung, Effect of sulfur on the mineral phases of laterite ores at high temperature reduction, Minerals Engineering, 15, 7, (2002), 523530 https://doi.org/10.1016/So892-6875(02)000699

[12] D. Q. Zhu, Y. Cui, K. Vining, S. Hapugoda, J. Douglas, J. Pan and G. L. Zheng, Upgrading low nickel content laterite ores using selective reduction followed by magnetic separation, International Journal of Mineral Processing, 106-109, (2012), 1-7 https://doi.org/10.1016/j.minpro.2012.01.003

[13] I. Setiawan, S. Harjanto and R. Subagja, LowTemperature Carbothermic Reduction of Indonesia Nickel Lateritic Ore with Sub-Bituminous Coal, IOP Conference Series: Materials Science and Engineering, 202, (2017), 012019 https://doi.org/10.1088/1757899x/202/1/012019

[14] Guanghui Li, Tangming Shi, Mingjun Rao, Tao Jiang and Yuanbo Zhang, Beneficiation of nickeliferous laterite by reduction roasting in the presence of sodium sulfate, Minerals Engineering, 32, (2012), 1926 https://doi.org/10.1016/j.mineng.2012.03.012

[15] Eni Febriana, Agung Tristiyan, Wahyu Mayangsari and Agus Budi Prasetyo, Kinetika dan Mekanisme Pelindian Limonit : Pengaruh Waktu dan Temperatur, Metalurgi, 33, 2, (2018), 61-68 http://dx.doi.org/10.14203/metalurgi.v33i2.420

[16] Eni Febriana, Azwar Manaf, AB Prasetyo and W Mayangsari, Thermal characteristic of limonite ore upon calcination and reduction, AIP Conference Proceedings, (2018) https://doi.org/10.1063/1.5038308 
[17] J. Li, K. Bunney, H. R. Watling and D. J. Robinson, Thermal pre-treatment of refractory limonite ores to enhance the extraction of nickel and cobalt under heap leaching conditions, Minerals Engineering, 41, (2013), 71-78

https://doi.org/10.1016/j.mineng.2012.11.002

[18] Man Jiang, Tichang Sun, Zhiguo Liu, Jue Kou, Na Liu and Shiyuan Zhang, Mechanism of sodium sulfate in promoting selective reduction of nickel laterite ore during reduction roasting process, International Journal of Mineral Processing, 123, (2013), 32-38 https://doi.org/10.1016/j.minpro.2013.04.005

[19]W. Mayangsari and A. B. Prasetyo, Phase Transformation of Limonite Nickel Ores with $\mathrm{Na}_{2} \mathrm{SO}_{4}$ Addition in Selective Reduction Process, IOP Conference Series: Materials Science and Engineering, 202, (2017), 012016

https://doi.org/10.1088/1757-899x/202/1/012016

[20]Ihsan Barin and Fried Sauert, Thermochemical Data of Pure Substances, VCH, 1993

[21] Nuryadi Saleh, Yuhelda, Pramusanto, Muchtar J. Aziz, Isyatun Rodliyah, Rezky Iriasyah, Eko Setyatmoko, Edy Suyatno and Pipih Hanapiah, Penelitian Reduksi Bijih Besi dan Nikel dalam Rotary Kiln Skala Pilot Plant dan Ekstraksi Bijih Mangan, in, Pusat Penelitian dan Pengembangan Teknologi Mineral dan Batubara, Bandung, 2012,

[22]Tetsuya Watanabe, Sadao Ono, Haruo Arai and Toyomi Matsumori, Direct reduction of garnierite ore for production of ferro-nickel with a rotary kiln at Nippon Yakin Kogyo Co., Ltd., Oheyama Works, International Journal of Mineral Processing, 19, 1, (1987), 173-187

https://doi.org/10.1016/0301-7516(87)90039-1

[23]E. C. Ferre and F. Martin-Hernandez, Magnetic properties of natural and synthetic olivines: highfield measurements, AGU Fall Meeting Abstracts, (2004) 